\title{
Antioxidant and biological activities of untreated and steam-treated Corni fructus extracts
}

\author{
Yul Ri Gu, Joo-Heon Hong* \\ ${ }^{1}$ Department of Food Science and Technology, Catholic University of Daegu, Gyeongsan 38430, Korea
}

\section{무처리 및 증숙처리 산수유 추출물의 항산화 및 생리활성}

\author{
구율리·홍주헌* \\ 대구가톨릭대학교 식품공학전공
}

\begin{abstract}
The aim of this study was to investigate functional food material for the antioxidant and biological activities of untreated and steam-treated Corni fructus extracts in extraction solvents (through hot-water extraction, $50 \%$ ethanol extraction, and 50\% methanol extraction). The yield of UCH (hot-water extract of untreated Corni fructus) was $47.45 \%$ and it was higher than those of extracts $(13.20-27.18 \%)$ obtained by the other extraction methods. The total phenolic and flavonoid contents were $12.23 \mathrm{~g} / 100 \mathrm{~g}$ (SCE, 50\% ethanol extract of steam-treated Corni fructus) and $5.08 \mathrm{~g} / 100 \mathrm{~g}$ (SCE), respectively, and the total sugar content was $71.32 \mathrm{~g} / 100 \mathrm{~g}$ (SCH, hot-water extract of steam-treated Corni fructus). The main organic acid components of the extracts were oxalic acid, citric acid, malic acid, formic acid, and gallic acid. The DPPH and ABTS radical scavenging activities of SCE at $1,000 \mu \mathrm{g} / \mathrm{mL}$ were $72.37 \%$ and $43.15 \%$, respectively. The feric-reducing antioxidant power of SCE at $1,000 \mu \mathrm{gg} / \mathrm{mL}$ was 689.49 $\mu M$. The extracts were investigated for their function in L-132, RAW 264.7, HeLa, and MCF-7 cell lines. The SCE performed better than the other extracts in terms of its protective effects against oxidative stress in L-132 cells and increased the production of NO. Further the SCE showed antitumor activities against HeLa and MCF-7 cancer cells. Therefore, the SCE extracts is a good functional food material for the prevention of woman disease. Therefore, in our study, the SCE extracts is good functional food material for the prevention of oxidant, immunological, and tumor related disease.
\end{abstract}

Key words : Corni fructus extract, steam-treat, antioxidant, biological activity

\section{서 론}

평균 수명이 길어지고 고령화 사회에 접어들면서 인간은 건강에 대한 관심이 높아지고 있으며, 이에 따라 "well-bing"이라는 트렌드가 부각되어 많은 관심이 집중되 고 있다. 그러나 바쁜 일상생활로 인해 스트레스, 식생활의 서구화, 외식의 증가 및 환경오염 등과 같은 건강에 악영향

*Corresponding author. E-mail : jhhong@cu.ac.kr Phone : 82-53-850-3218, Fax : 82-53-850-3218

Received 9 May 2018; Revised 14 June 2018; Accepted 15 June 2018.

Copyright (c) The Korean Society of Food Preservation. All rights reserved.
을 줄 수 있는 위해 요소로 인해 다양한 질환이 발생하게 된다 $(1,2)$. 이러한 인체의 노화 및 여러 질환의 발생은 많은 연구를 통해 프리라디칼인 활성산소종(reactive oxygen species, ROS)과 깊은 관계가 있음이 밝혀지고 있다(3). 활 성산소종은 쌍을 이루지 못한 전자에 의해 높은 반응성을 가지는 산소 원자나 분자를 말하며, 세포생체막의 인지질 중 불포화지방산을 공격하여 과산화지질을 생성하고 축적 함으로서 세포 손상을 일으켜 염증을 유발하여 면역을 저하 시키거나 DNA를 손상시켜 암을 유발하기도 한다 $(4,5)$. 인 체 내에서 일어나는 산화 반응은 노화, 염증 및 암 등을 유발하므로 이러한 활성산소를 소거하기 위한 항산화성 물질에 대한 연구가 활발히 진행되고 있으며, 최근 안전성 문제로 천연식품 유래 항산화물질을 찾고자 노력하고 있다 $(6,7)$. 
산수유나무(Cornus officinalis)는 층층나무과에 속하는 낙엽활목이며 오래전부터 가을에 성숙한 산수유나무의 붉 은 열매인 산수유(Corni fructus)를 따서 씨를 뽑아내고 햇볕 에 말린 것을 한약재로 많이 사용하고 있다 $(8,9)$. 독특한 향과 강한 신맛 및 약간의 단맛을 내고 성질이 따뜻하여 간과 신장의 기운을 북돋아주고 항암효과, 항균효과, 이뇨 작용 및 혈압강하작용 등이 있으며, 단백질의 소화를 돕는 작용 등이 있다고 한방자료에 기록되어 있다(10). 산수유의 성분으로는 malic acid, tartaric acid, gallic acid, ursolic acid 등 유기산과 morroniside, loganin, sweroside, methylmorroniside 등 iridoid 배당체(11) 및 tellimagrandin 1, tellinagrandin 2, isoterchebin(Cornus-tannin 1), gemin D, Cornusiin A, B, C와 1,7-di-O-galloyl-D-sedoheptullose, Cornusiin D, E, F와 같은 $\operatorname{tannin}$ 류(12)가 있다. 산수유에 대한 연구로는 항산화 활성 $(13,14)$, 항균작용(10), 항암효과(15)와 유용성분에 대한 연 구(16)가 있으나, 산수유의 강한 신맛으로 인해 이를 활용한 식품 산업적 활용은 제한적이다.

증숙 공정은 증기를 이용해 구성성분을 변화시켜 새로운 화합물을 만들어내고, 유용성분의 용출을 극대화하는 장점 을 가지고 있다. 일반적으로 열처리 공정은 식물의 조직성 분을 연소시키며 활성성분을 파괴하여 수율 및 생리활성을 감소시키는 단점이 있다. 이러한 단점을 보완하기 위해 직 접적 열처리가 아닌 간접적 열처리인 증기를 이용하여 유용 성분의 용출을 증진시킬 수 있는 증숙 공정이 이용되고 있다 $(17,18)$. 증숙 관련 연구로는 도라지(19), 인삼(20) 및 마(21) 등에 적용하여 원료의 쓴맛 성분을 제거하거나 감소 시켜 기호성을 향상시키고, 유용성분의 변화를 유도하여 기능성 향상 및 제품개발을 위한 품질특성 개선 등 다양한 분야에 적용되고 있다.

따라서 본 연구에서는 산수유의 유용성분의 용출을 향상 시키고 산수유의 강한 신맛을 감소시키기 위해 증숙 공정을 전처리로 적용하였으며, 추출용매에 따른 산수유 추출물의 항산화, 면역활성 및 항암 효과를 비교 분석하여, 기능성 식품소재로의 활용 증대 가능성을 조사하였다.

\section{재료 및 방법}

\section{실험재료}

건산수유(Corni fructus, 국내산)는 의성농산영농조합법 인에서 구입하였으며, 실험재료는 $-20^{\circ} \mathrm{C}$ 이하 암소에 보관 하며 실험에 사용하였다.

\section{산수유 추출물 제조}

산수유 추출물을 제조하기 위한 전처리 공정으로 건산수 유를 상온에서 증류수에 3 시간 수침하여 불린 후, 가정용 찜솥에서 $100^{\circ} \mathrm{C}, 1$ 시간 증숙한 다음 열풍건조기 $(\mathrm{OF}-22$,
Jeiotech, Seoul, Korea)로 $50^{\circ} \mathrm{C}, 6$ 시간 건조하였다. 무처리 (건산수유) 및 증숙 산수유를 건식분쇄기(NSG-1002SS, Hanil, Sejong, Korea)로 각각 분쇄한 다음 표준망체(60 mesh, Chung Gye Sang Cong Sa, Seoul, Korea)에 통과한 분말 $30 \mathrm{~g}$ 에 증류수, $50 \%$ 에탄올 및 $50 \%$ 메탄올을 고형분 대비 10 배 첨가하였다. 증류수 첨가구는 $100^{\circ} \mathrm{C}, 50 \%$ 에탄올 및 $50 \%$ 메탄올 첨가구는 $70^{\circ} \mathrm{C}$ 에서 5 시간 동안 환류냉각추 출기(CA-1112, Eyela Co., Tokyo, Japan)를 사용하여 추출하 였고 각각의 추출물은 불순물을 제거하기 위해 여과지 (No.2, Whatman International Ltd., Leicestershire, England) 를 이용하여 여과하였다. 여과된 시료는 감압농축기(Model N-1N, Eyela Co., Tokyo, Japan)로 농축한 다음, 동결건조기 (Free Zone 2.5, Labconco Co., Kansas, MO, USA)를 사용하 여 건조한 뒤 $-70^{\circ} \mathrm{C}$ 이하의 암소에서 보관하면서 실험에 사용하였다.

\section{추출수율}

산수유 추출물의 수율은 동결건조(Free Zone 2.5, Labconco Co.)한 다음 건물 중량을 구하였고 시료 조제에 사용한 원료 건물량에 대한 백분율로 나타내었다.

\section{총 폴리페놀, 총 플라보노이드 및 총 당 함량}

총 폴리페놀 함량은 Folin-Denis법(22)에 따라 시료 $1 \mathrm{~mL}$ 에 $1 \mathrm{~N}$ Folin Ciocalteu reagent $1 \mathrm{~mL}$ 를 첨가하고 충분히 혼합한 다음 $20 \% \mathrm{Na}_{2} \mathrm{CO}_{3} 1 \mathrm{~mL}$ 를 첨가하여 실온의 암소에 서 30 분간 반응시킨 후 분광광도계(Ultrospec 2100pro, Biochrom Ltd., Cambridge, UK)를 이용하여 $725 \mathrm{~nm}$ 에서 흡광도를 측정하였다. 총 폴리페놀 함량은 tannic acid (Sigma-Aldrich Co.)를 사용하여 작성한 표준곡선으로부터 계산하였다.

총 플라보노이드 함량은 $\mathrm{Jia}$ 등(23)의 방법을 응용하여 측정하였다. 시료 $1 \mathrm{~mL}$ 에 $5 \% \mathrm{NaNO}_{2} 0.15 \mathrm{~mL}$ 를 혼합하여 실온에서 6분간 반응 시킨 후 $10 \% \mathrm{AlCl}_{3} 0.3 \mathrm{~mL}$ 와 혼합하여 다시 실온에서 5 분간 반응 시키고 $1 \mathrm{~N} \mathrm{NaOH} 1 \mathrm{~mL}$ 와 혼합한 다음 분광광도계(Ultrospec 2100pro, Biochrom Ltd.)를 이용 하여 $510 \mathrm{~nm}$ 에서 흡광도를 측정하였다. 총 플라보노이드함 량은 rutin(Sigma-Aldrich Co.)을 사용하여 작성한 표준곡선 으로부터 계산하였다.

총 당 함량은 phenol-sulfuric acid 방법(24)을 응용하여 측정하였다. 시료 $1 \mathrm{~mL}$ 와 $5 \%$ phenol $1 \mathrm{~mL}$ 및 진한 $\mathrm{H}_{2} \mathrm{SO}_{4}$ $5 \mathrm{~mL}$ 를 혼합하여 20 분간 반응 시킨 후, 분광광도계 (Ultrospec 2100pro, Biochrom Ltd)를 이용하여 $470 \mathrm{~nm}$ 에서 흡광도를 측정하였다. 총 당 함량은 glucose(Sigma-Aldrich Co.)을 사용하여 작성한 표준곡선으로부터 계산하였다.

\section{유기산 함량 측정}

유기산 함량은 high performance liquid chromatography 
(HPLC)를 이용하여 분석하였으며, 시료는 증류수에 희석 하여 $10 \mathrm{mg} / \mathrm{mL}$ 농도로 제조한 다음 $0.45 \mu \mathrm{m}$ membrane filter(Waters Co., Milford, MA, USA)로 여과하여 분석용 시료로 사용하였다. Alliance HPLC system 2695 (Waters Co.)를 이용하여 photodiode array detector 2996 (Waters Co.) 로 분석하였다. 분석용 컬럼은 Shodex SUGAR SH-1011(partivle size $6 \mu \mathrm{m}, 8.0 \times 300 \mathrm{~mm}$, Showa Denko Co., Tokyo, Japan)를 사용하였으며, 분석용 용매는 $20 \mathrm{mM}$ $\mathrm{H}_{2} \mathrm{SO}_{4}$ 를 사용하였다. 분석용 컬럼 온도는 $60^{\circ} \mathrm{C}$, 유속은 0.6 $\mathrm{mL} / \mathrm{min}$ 으로 설정하였으며, 시료를 $10 \mu \mathrm{L}$ 주입하고 detector 파장 $210 \mathrm{~nm}$ 에서 측정하였다. 유기산 함량은 표준물질을 이용하여 작성한 표준곡선으로 정량하였으며, 표준물질은 Sigma-Aldrich Co.로부터 구입하여 사용하였다.

\section{$\mathrm{DPPH}$ radical 소거활성 측정}

$\mathrm{DPPH}$ radical 소거활성 은 1,1-diphenyl-2-pycrylhydrazyl $(\mathrm{DPPH})$ 의 환원력을 이용하여 측정하였다(2). 즉, $\mathrm{DPPH}$ reagent는 DPPH $12 \mathrm{mg}$ 을 absolute ethanol $100 \mathrm{~mL}$ 에 용해한 후 증류수 $100 \mathrm{~mL}$ 첨가하여 흡광도를 $517 \mathrm{~nm}$ 에서 약 1.5 로 조정하여 제조하였다. 시료 $0.5 \mathrm{~mL}$ 에 DPPH reagent $5 \mathrm{~mL}$ 를 혼합하여 실온에서 15 분간 반응시킨 후 분광광도계 (Ultrospec 2100pro, Biochrom Ltd.)로 흡광도를 측정하고 아래와 같이 계산하였다.

DPPH radical scavenging activity $(\%)=\left(1-\frac{S}{C}\right) \times 100$

S : absorbance of sample at $517 \mathrm{~nm}$

C : absorbance of control at $517 \mathrm{~nm}$

\section{ABTS radical 소거활성 측정}

2,2' -azino-bis(3-ethylbenzothiazoline-6-sulfonic acid)(ABTS) radical 소거활성(25)은 $7.4 \mathrm{mM}$ ABTS(SigmaAldrich Co.)와 $2.45 \mathrm{mM}$ potassium persulfate를 최종 농도로 혼합하여 실온인 암소에서 24시간 동안 방치하여 ABTS+ 을 형성시킨 후 $732 \mathrm{~nm}$ 에서 흡광도 값이 $0.70 \pm 0.02$ 가 되게 phosphate buffer saline(PBS, pH 7.4)으로 희석하였다. 희석 된 용액 $180 \mu \mathrm{L}$ 에 시료 $20 \mu \mathrm{L}$ 를 혼합하여 정확히 10 분간 반응시킨 다음 분광광도계(Ultraspec 2100pro, Biochrom Ltd.)를 이용하여 $732 \mathrm{~nm}$ 에서 흡광도를 측정하였다. ABTS radical 소거활성은 추출물의 첨가 전과 후의 차이를 아래와 같이 백분율로 나타내었다.

ABTS radical scavenging activity $(\%)=\left(1-\frac{S}{C}\right) \times 100$

S : absorbance of sample at $732 \mathrm{~nm}$

C : absorbance of control at $732 \mathrm{~nm}$
Ferric reducing antioxidant power(FRAP) 측정

FRAP는 Benzie와 Strain의 방법(26)에 따라 다음과 같이 측정하였다. FRAP reagent는 $25 \mathrm{~mL}$ acetate buffer $(300 \mathrm{mM}$, $\mathrm{pH} 3.6$ )를 $37^{\circ} \mathrm{C}$ 에서 가온한 후, $40 \mathrm{mM} \mathrm{HCl}$ 에 용해한 10 $\mathrm{mM}$ 2,4,6-tris(2-pyridyl)-s-triazine(TPTZ, Sigma-Aldrich Co.) $2.5 \mathrm{~mL}$ 와 $20 \mathrm{mM}$ ferric chloride $\left(\mathrm{FeCl}_{3}\right) 2.5 \mathrm{~mL}$ 를 첨가하 여 제조하였다. 시료 $30 \mu \mathrm{L}$ 에 제조된 FRAP reagent 900 $\mu \mathrm{L}$ 와 증류수 $90 \mu \mathrm{L}$ 를 넣은 후 $37^{\circ} \mathrm{C}$ 에서 10 분간 반응시킨 다음 분광광도계(Ultraspec 2100pro, Biochrom Ltd.)를 이용 하여 $510 \mathrm{~nm}$ 에서 흡광도를 측정하였다. FRAP는 $\mathrm{FeSO}_{4} \cdot 7 \mathrm{H}_{2} \mathrm{O}$ (Sigma-Aldrich Co.)을 정량하여 작성한 표준 곡선으로부터 계산하였다.

\section{세포주 배양 및 세포 독성}

실험에 사용한 인간 폐상피세포주(L-132), 마우스 대식 세포주(RAW264.7), 인간 자궁경부암 세포주(HeLa) 및 인 간 유방암 세포주(MCF-7)는 한국세포주은행(KTCC, Seoul, Korea)에서 분양받았다. L-132 및 RAW264.7 세포주는 DMEM 배지(Welgene Co., Daegu, Korea)를 이용하였으며, HeLa 및 MCF-7 세포주는 RPMI 1640 배지(Welgene Co.)를 이용하여 $10 \%$ fetal bovine serum(Gibco BRL Co., Grand Island, NY, USA) 및 $2 \%$ penicillin-streptomycin(Gibco BRL Co.)을 첨가한 다음 $37^{\circ} \mathrm{C}, 5 \% \mathrm{CO}_{2}$ incubator(MCO-18 $\mathrm{AIC}$, Sanyo Eletric Biomedical Co., Ltd., Osaka, Japan)에서 배양 하였다.

세포 독성은 MTT assay를 이용하여 측정하였으며, 배양 된 세포주를 $1 \times 10^{4}$ cell/well의 농도로 조정하여 96-well plate에 $100 \mu \mathrm{L}$ 씩 첨가하고 24시간 동안 배양한 후 새로운 배지 교환 및 시료를 농도별로 처리한 다음 24시간 동안 배양하였다. 배양 후 PBS 완충용액에 녹인 methyl thiazol-2-YL-2,5-diphenyl tetrazolium bromide(MTT 5 $\mathrm{mg} / \mathrm{mL}$, Sigma-Aldrich Co.) 용액을 각 well에 $10 \mu \mathrm{L}$ 씩 첨가 하고 4시간 동안 배양하여 MTT가 환원되도록 하였다. 이후 상등액을 모두 제거하고 dimethyl sulfoxide(DMSO, Jensei Chemical Co., Tokyo, Japan) $100 \mu \mathrm{L}$ 를 각 well에 첨가하여 10 분간 반응시켜 formazan 결정을 용해한 다음 microplate reader(UVM-340, Asys Co., Biochrom, Cambridge, UK)를 이용하여 흡광도 파장 $540 \mathrm{~nm}$ 에서 측정하였다.

\section{세포보호효과 측정}

L-132 세포를 이용한 세포보호 효과는 Hwang(27)의 방 법을 응용하여 측정하였다. 배양된 L-132 세포를 $1 \times 10^{4}$ cell/well의 농도로 조정하여 96-well plate에 $100 \mu \mathrm{L}$ 씩 첨가 하여 24시간 동안 배양하고 이후 새로운 배지 교환 및 $\mathrm{H}_{2} \mathrm{O}_{2}$ (Duksan pure chemicals Co., Ansan, Korea) $1.25 \mathrm{mM}$ 과 시료를 농도별로 처리한 다음 6시간 동안 배양하였다. 배양 후 PBS 완충용액에 녹인 methyl thiazol-2-YL-2,5-diphenyl 
tetrazolium bromide(MTT $5 \mathrm{mg} / \mathrm{mL}$, Sigma-Aldrich Co.) 용 액을 각 well에 $10 \mu \mathrm{L}$ 씩 첨가하고 2시간 동안 배양하여 MTT가 환원되도록 하였다. 이후 상등액을 모두 제거하고 dimethyl sulfoxide(DMSO, Jensei Chemical Co.) $100 \mu \mathrm{L}$ 를 각 well에 첨가하여 10 분간 반응시켜 formazan 결정을 용해 한 다음 microplate reader(UVM-340, Asys Co.)를 이용하여 흡광도 파장 $540 \mathrm{~nm}$ 에서 측정하였다.

\section{Nitric oxide 생성량 측정}

RAW264.7 세포를 $5 \times 10^{4}$ cell/well의 농도로 조정하여 96-well plate에 각각 $100 \mu \mathrm{L}$ 씩 첨가하여 24시간 동안 배양 하고, 농도별 시료 및 lipopolysaccharide(LPS $0.1 \mu \mathrm{g} / \mathrm{mL}$, Sigma-Aldrich Co.)를 처리하여 24시간 동안 배양하였다. 배양이 완료된 후 상등액 $50 \mu \mathrm{L}$ 에 동량의 Griess 시약 (Sigma-Aldrich Co.) $50 \mu \mathrm{L}$ 를 혼합하여 10 분간 반응시키고 microplate reader(UVM-340, Asys Co.)를 이용하여 $540 \mathrm{~nm}$ 에서 흡광도를 측정하였으며, NO 생성량은 sodium nitrite(Sigma-Aldrich Co.)의 농도별 표준곡선을 이용하여 계산하였다.

\section{암세포 생육 저해활성 측정}

암세포 생육 저해활성은 MTT assay를 이용하여 측정하 였으며, 배양된 세포주를 $2 \times 10^{4} \mathrm{cell} / \mathrm{well}$ 의 농도로 조정하 여 96-well plate에 $100 \mu \mathrm{L}$ 씩 첨가하고 24시간 동안 배양하 고 이후 새로운 배지 교환 및 시료를 농도별로 처리한 다음 24시간 동안 배양하였다. 배양 후 PBS 완충용액에 녹인 methyl thiazol-2-YL-2,5-diphenyl tetrazolium bromide(MTT $5 \mathrm{mg} / \mathrm{mL}$, Sigma-Aldrich Co.) 용액을 각 well에 $10 \mu \mathrm{L}$ 씩 첨가하고 4시간 동안 배양하여 MTT가 환원되도록 하였다. 이후 상등액을 모두 제거하고 dimethyl sulfoxide(DMSO, Jensei Chemical Co.) $100 \mu \mathrm{L}$ 를 각 well에 첨가하여 10 분간 반응시켜 formazan 결정을 용해한 다음 microplate reader(UVM-340, Asys Co.)를 이용하여 흡광도 파장 540 $\mathrm{nm}$ 에서 측정하였다.

\section{통계처리}

모든 실험결과는 IBM SPSS Statistics(19.0, IBM Corp., Armonk, NY, USA)를 이용한 분산분석(ANOVA)을 실시하 였고 각 측정 평균값의 유의성 $(\mathrm{p}<0.05)$ 은 Duncan's multiple range test를 실시하여 검정하였다.

\section{결과 및 고찰}

\section{산수유 추출물의 이화학적 특성}

추출용매에 따른 무처리 및 증숙 산수유의 추출수율, 총 폴리페놀, 총 플라보노이드 및 총 당 함량은 Table 1 과 같다.
추출수율은 무처리 산수유 열수추출물에서 $47.45 \%$ 로 높은 수율을 나타내었는데, 이는 산수유에 수용성 성분의 함량 이 많은 것으로 나타났다. 또한 증숙 산수유보다 무처리 산수유의 수율이 더 높게 나타난 것은 증숙 공정을 통해 산수유의 고형물이 유출된 것으로 판단된다. 식물에 많이 분포되어 있는 페놀성 물질은 2차 대사산물로 phenolic hydroxyl기를 가지고 있다. 이로 인해 단백질 및 기타 분자 들과 결합하는 성질을 지니고 있으며, 항산화 효과의 기능 을 갖는다(28). 총 폴리페놀 함량은 증숙 산수유 $50 \%$ 에탄 올 추출물에서 $12.23 \mathrm{~g} / 100 \mathrm{~g}$ 으로 가장 높은 함량을 나타내 었고 무처리 산수유 추출물보다 높은 함량을 나타내었는 데, 이는 $\mathrm{Kim}$ 등(29)이 보고한 산수유의 총 폴리페놀 함량 $(3.23 \mathrm{~g} / 100 \mathrm{~g})$ 보다 약 2-4배 이상 높게 나타났다. 총 플라보 노이드 함량은 총 폴리페놀 함량과 같이 증숙 산수유 $50 \%$ 에탄올 추출물에서 $5.08 \mathrm{~g} / 100 \mathrm{~g}$ 으로 가장 높은 함량을 나타 내었으며, 무처리 산수유 추출물보다 높았다. 이와 같은 결과는 증숙 공정을 통해 총 페놀성 화합물의 함량이 증가 하는 것으로 보고되는데, 이는 결합형 페놀성분이 열에 의 해 유리형으로 바뀌어 용출되거나 고분자가 저분자로 분해 되어 그 함량이 증가한 것으로 보고하였다(30). 총 당 함량 은 증숙 산수유 열수추출물에서 $71.32 \mathrm{~g} / 100 \mathrm{~g}$ 으로 가장 높은 함량을 나타내었으며, 모든 추출용매에서 증숙 전처 리를 통해 총 당 함량이 증가하였다. 이러한 결과는 증숙 공정을 통해 다당체 성분이 가용화되어 나타난 결과로 판단 된다(31).

Table 1. The yield, total phenolic, total flavonoid, and total sugar contents of extracts from non-steaming and steaming corni fructus

\begin{tabular}{ccccc}
\hline Samples $^{1)}$ & $\begin{array}{c}\text { Yield } \\
(\text { Dry basis, \%) }\end{array}$ & $\begin{array}{c}\text { Total polyphenol } \\
\left(\mathrm{TA}^{2)}, \mathrm{g} / 100 \mathrm{~g}\right)\end{array}$ & $\begin{array}{c}\text { Total flavonoid } \\
(\text { Rutin, g/100 g) }\end{array}$ & $\begin{array}{c}\text { Total sugar } \\
(\text { Glucose, g/100 g) }\end{array}$ \\
\hline UCH & $47.45 \pm 0.22^{\mathrm{a})}$ & $8.56 \pm 0.27^{\mathrm{c}}$ & $3.37 \pm 0.11^{\mathrm{d}}$ & $61.13 \pm 1.28^{\mathrm{c}}$ \\
SCH & $27.18 \pm 0.19^{\mathrm{b}}$ & $11.00 \pm 0.20^{\mathrm{b}}$ & $4.50 \pm 0.08^{\mathrm{b}}$ & $71.32 \pm 1.47^{\mathrm{a}}$ \\
UCE & $16.87 \pm 0.06^{\mathrm{d}}$ & $8.90 \pm 0.26^{\mathrm{c}}$ & $3.84 \pm 0.07^{\mathrm{c}}$ & $64.77 \pm 1.95^{\mathrm{b}}$ \\
SCE & $13.20 \pm 0.11^{\mathrm{f}}$ & $12.23 \pm 0.05^{\mathrm{a}}$ & $5.08 \pm 0.21^{\mathrm{a}}$ & $66.02 \pm 1.24^{\mathrm{b}}$ \\
UCM & $25.27 \pm 0.24^{\mathrm{c}}$ & $7.71 \pm 0.38^{\mathrm{d}}$ & $3.30 \pm 0.14^{\mathrm{d}}$ & $63.18 \pm 1.57^{\mathrm{bc}}$ \\
SCM & $15.33 \pm 0.04^{\mathrm{e}}$ & $10.54 \pm 0.59^{\mathrm{b}}$ & $4.33 \pm 0.05^{\mathrm{b}}$ & $65.07 \pm 2.62^{\mathrm{b}}$ \\
\hline
\end{tabular}

${ }^{1)} \mathrm{UCH}$, hot-water extract of untreated Corni fructus, SCH, hot-water extract of steam-treated Corni fructus, UCE, 50\% ethanol extract of untreated Corni fructus, SCE, 50\% ethanol extract of steam-treated Corni fructus, UCM, 50\% methanol extract of untreated Corni fructus, SCM, 50\% methanol extract of steam-treated Corni fructus.

${ }^{2)} \mathrm{TA}$, tannic acid.

${ }^{3)}$ Means \pm SD ( $n=3$ ) with different letters ( $\left.\mathrm{a}-\mathrm{f}\right)$ above bars are significant differences by Duncan's multiple range test $(\mathrm{p}<0.05)$.

\section{산수유 추출물의 유기산 함량}

추출용매에 따른 무처리 및 증숙 산수유 추출물의 유기 산 함량은 Table 2 와 같다. 산수유의 유기산 성분으로 gallic acid, malic acid 및 tartaric acid(11)가 이미 알려져 있으며, 본 연구에서는 oxalic acid, citric acid, malic acid, formic 
acid 및 gallic acid가 검출되었다. 그 중에서 oxalic acid 및 citric acid는 각각 7.07-16.30 g/100 g 및 6.94-15.95 g/100 $\mathrm{g}$ 으로 가장 높은 함량을 나타내었으며, 증숙 공정을 통해 citric acid, malic acid 및 formic acid는 감소하였으나, oxalic acid 및 gallic acid가 증가하였다. 이는 증숙 공정으로 인해 fructose가 분해되어 5-methyl furfural, HMF 및 furfural 등과 유기산으로 분해되어(32), 증숙 산수유의 일부 유기산 함량 이 증가한 것으로 판단된다. 특히 gallic acid는 항암효과가 있는 것으로 알려져 있어 증숙 산수유의 항암활성이 무처리 산수유보다 우수할 것으로 판단된다. 또한 증숙 공정을 통 해 전체적인 유기산 함량이 감소하여 식품소재 활용 면에서 제한되었던 산수유의 강한 신맛을 보완하였다.

Table 2. Organic acid contents of extracts from non-steaming and steaming corni fructus

\begin{tabular}{cccccc}
\hline \multirow{2}{*}{ Samples $^{1)}$} & \multicolumn{5}{c}{ Organic acid $(\mathrm{g} / 100 \mathrm{~g})$} \\
\cline { 2 - 6 } & Oxalic acid & Citric acid & Malic acid & Formic acid & Gallic acid \\
\hline UCH & $11.22 \pm 1.85^{\mathrm{c} 2)}$ & $15.95 \pm 0.30^{\mathrm{a}}$ & $4.09 \pm 0.30^{\mathrm{bc}}$ & $2.17 \pm 0.01^{\mathrm{b}}$ & $1.97 \pm 0.04^{\mathrm{c}}$ \\
SCH & $16.30 \pm 0.27^{\mathrm{a}}$ & $10.41 \pm 0.68^{\mathrm{c}}$ & $2.28 \pm 0.05^{\mathrm{d}}$ & $2.01 \pm 0.04^{\mathrm{b}}$ & $2.93 \pm 0.06^{\mathrm{b}}$ \\
UCE & $7.07 \pm 0.42^{\mathrm{d}}$ & $12.99 \pm 0.24^{\mathrm{b}}$ & $5.28 \pm 0.31^{\mathrm{a}}$ & $2.51 \pm 0.46^{\mathrm{a}}$ & $1.32 \pm 0.05^{\mathrm{d}}$ \\
SCE & $13.21 \pm 0.73^{\mathrm{b}}$ & $6.94 \pm 0.20^{\mathrm{d}}$ & $4.38 \pm 0.05^{\mathrm{b}}$ & $2.16 \pm 0.02^{\mathrm{b}}$ & $3.58 \pm 0.19^{\mathrm{a}}$ \\
UCM & $11.14 \pm 0.30^{\mathrm{c}}$ & $13.26 \pm 0.20^{\mathrm{b}}$ & $5.35 \pm 0.02^{\mathrm{a}}$ & $1.97 \pm 0.04^{\mathrm{b}}$ & $1.71 \pm 0.00^{\mathrm{c}}$ \\
SCM & $13.49 \pm 0.42^{\mathrm{b}}$ & $10.82 \pm 0.07^{\mathrm{c}}$ & $3.98 \pm 0.17^{\mathrm{c}}$ & $1.86 \pm 0.02^{\mathrm{b}}$ & $3.00 \pm 0.44^{\mathrm{b}}$ \\
\hline
\end{tabular}

${ }^{1)} \mathrm{UCH}$, hot-water extract of untreated Corni fructus, SCH, hot-water extract of steam-treated Corni fructus, UCE, 50\% ethanol extract of untreated Corni fructus, SCE, 50\% ethanol extract of steam-treated Corni fructus, UCM, 50\% methanol extract of untreated Corni fructus, SCM, 50\% methanol extract of steam-treated Corni fructus

${ }^{2)}$ Means $\pm \mathrm{SD}(\mathrm{n}=3)$ with different letters $(\mathrm{a}-\mathrm{d})$ above bars are significant differences by Duncan's multiple range test $(\mathrm{p}<0.05)$.

\section{산수유 추출물의 항산화 활성}

추출용매에 따른 무처리 및 증숙 산수유 추출물의 DPPH radical 소거활성, ABTS radical 소거활성 및 FRAP 활성은 Fig. 1 과 같다. 약용열매의 항산화 물질 중 페놀화합물들은 우수한 항산화 효과를 가지는 것으로 보고되어 있으며, 이 는 free radical의 안정화를 시킬 수 있는 phenol ring에 의한 것으로 보고되어져 있다(33). DPPH 및 ABTS radical 소거 활성은 증숙 산수유 $50 \%$ 에탄올 추출물 $(1,000 \mathrm{\mu g} / \mathrm{mL})$ 에서 각각 $72.37 \%$ 및 $43.15 \%$ 로 높은 활성을 나타내었다. Radical 소거활성은 $50 \%$ 에탄올, $50 \%$ 메탄올 및 열수 추출물 순으 로 활성이 높게 나타났으며, 모든 추출용매에서 증숙 공정 을 통해 활성이 증가하였음을 확인하였다. Choo 등(34)의 연구에서 오미자의 증숙 횟수에 비례하여 DPPH 및 ABTS radical 소거활성이 증가함을 보고하였고, Yang 등(35)의 연구에서는 인삼에 증숙 공정을 적용함으로써 페놀화합물 의 함량이 변화하며 이에 따라 항산화 활성도 증가한다고 보고하여 본 연구결과와 유사한 경향을 나타내었다. 추출 용매에 따른 무처리 및 증숙 산수유 추출물의 FRAP 활성은

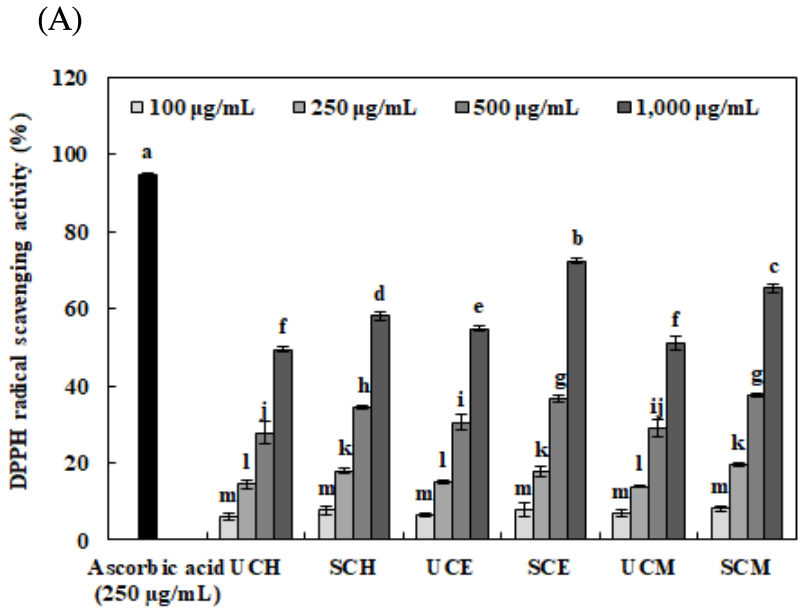

(B)

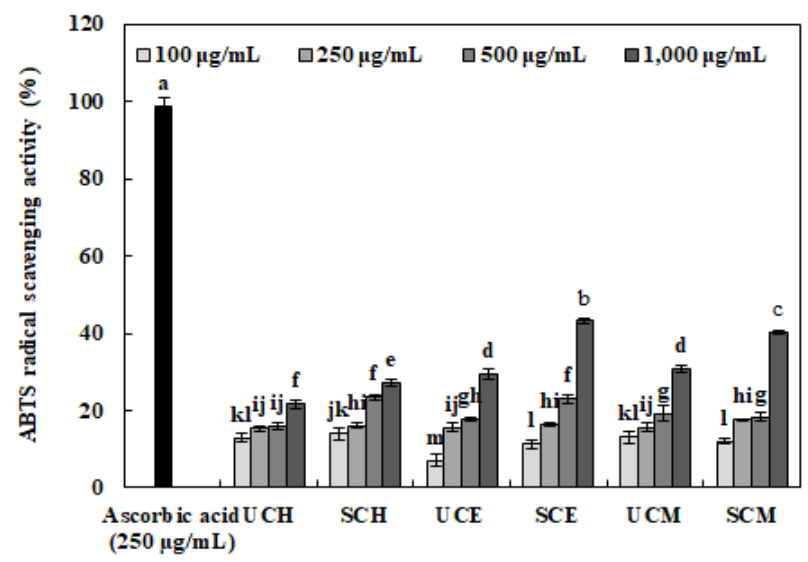

(C)

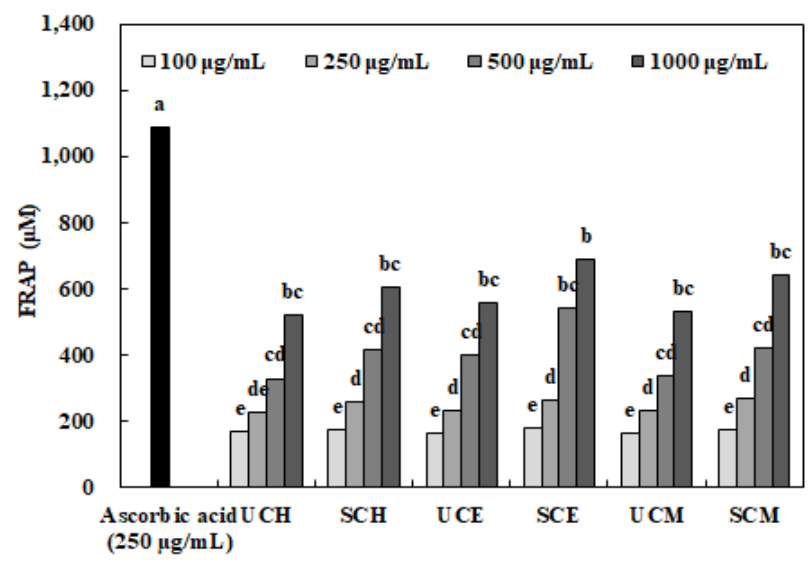

Fig. 1. DPPH radical scavenging activity (A), ABTS radical scavenging activity (B), and FRAP (ferric reducing antioxidant power) activity of extracts form untreated and steam-treated corni fructus.

UCH, hot-water extract of untreated Corni ffuctus, SCH, hot-water extract of steam-treated Corni fructus, UCE, 50\% ethanol extract of untreated Corni fructus, SCE, 50\% ethanol extract of steam-treated Corni fructus, UCM, 50\% methanol extract of untreated Corni fructus, SCM, 50\% methanol extract of steam-treated Corni fructus.

Means \pm SD ( $\mathrm{n}=3$ ) with different letters (a-m) above bars are significant differences by Duncan's multiple range test $(\mathrm{p}<0.05)$. 
증숙 산수유의 $50 \%$ 에탄올 추출물 $(1,000 \mu \mathrm{g} / \mathrm{mL})$ 에서 $689.49 \mu \mathrm{M}$ 으로 높은 활성을 나타내었다. 추출용매를 달리 한 각 추출물은 증숙 공정을 통해 활성이 증가하였음을 확인하여 이러한 결과는 앞선 DPPH 및 ABTS radical 소거 활성의 결과와 유사하였다. 이는 대표적인 항산화 성분인 페놀화합물이 증숙 공정에 의해 증가하여 항산화 활성이 높아진 것으로 사료된다(36).

\section{세포보호효과}

추출용매에 따른 무처리 및 증숙 산수유 추출물의 인간 폐상피세포인 L-132 세포에 대한 세포 독성 및 세포보호효 과는 Fig. 2와 같다. 추출용매에 따른 무처리 및 증숙 산수유 추출물은 $100,250,500$, 및 $1,000 \mu \mathrm{g} / \mathrm{mL}$ 로 처리하였으며,

\section{(A)}

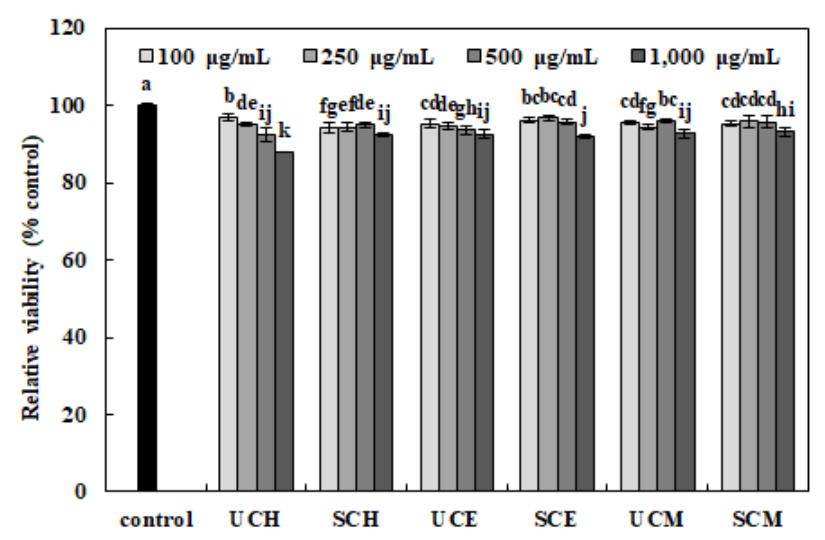

(B)

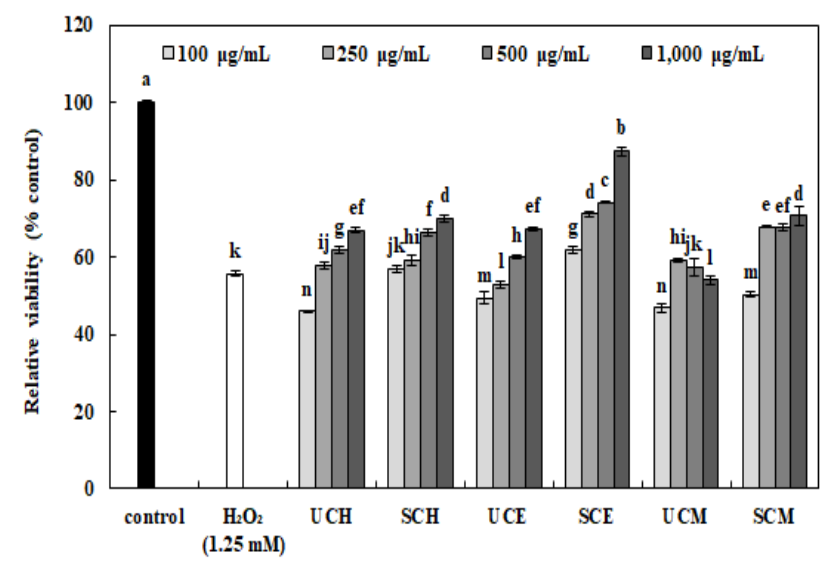

Fig. 2. Cell viability (A) and protective effects on cell viability against $\mathrm{H}_{2} \mathrm{O}_{2}(1.25 \mathrm{mM})$ induced oxidative damagein (B) in L-132 cell line of extracts from untreated and steam-treated corni fructus. UCH, hot-water extract of untreated Corni fructus, SCH, hot-water extract of steam-treated Corni fructus, UCE, 50\% ethanol extract of untreated Corni fructus, SCE, 50\% ethanol extract of steam-treated Corni fructus, UCM, 50\% methanol extract of untreated Corni fructus, SCM, 50\% methanol extract of steam-treated Corni fructus.

Means $\pm S D(n=3)$ with different letters $(a-n)$ above bars are significantly different by Duncan's multiple range test $(\mathrm{p}<0.05)$.
모든 농도 구간에서 세포 생존율을 $90 \%$ 이상으로 유지시켜 L-132 세포에 대한 독성이 낮음을 확인하였다.

추출용매에 따른 무처리 및 증숙 산수유 추출물의 세포 내 항산화 활성을 측정하기 위해 각 농도별 시료와 1.25 $\mathrm{mM} \mathrm{H} \mathrm{H}_{2}$ 를 처리하여 산화적 스트레스 $\left(\mathrm{H}_{2} \mathrm{O}_{2}\right)$ 에 대한 세포 생존율의 차이를 평가한 결과는 대체로 모든 시료에서 농도 가 증가함에 따라 세포생존율이 증가하는 경향을 보였으 며, 추출용매에 관계없이 증숙 산수유 추출물의 세포생존 율이 무처리 산수유 추출물보다 높게 나타났다. 특히 증숙 산수유의 $50 \%$ 에탄올 추출물 $(100-1,000 \mu \mathrm{g} / \mathrm{mL})$ 에서 61.88 $87.37 \%$ 로 가장 높은 세포생존율을 나타내어, $\mathrm{H}_{2} \mathrm{O}_{2}$ 에 의해 유도된 L-132 세포보호 효과가 높은 것으로 확인하였다. 이는 앞선 항산화 활성 측정 결과와 세포내 항산화 활성 측정 결과와 유사하게 나타났음을 확인하였으며, 증숙 산 수유의 $50 \%$ 에탄올 추출물에는 $\mathrm{H}_{2} \mathrm{O}_{2}$ 에 의해 유도된 세포 손상으로부터 보호효과를 보이는 다양한 페놀화합물을 포 함한 생리활성물질이 다량 함유되어 있을 것으로 판단된다 (37).

\section{Nitric oxide 생성량}

추출용매에 따른 무처리 및 증숙 산수유 추출물의 대식 세포인 RAW264.7 세포에 대한 세포 독성 및 nitric oxide 생성량은 Fig. 3 과 같다. 추출용매에 따른 무처리 및 증숙 산수유 추출물은 $100,250,500$, 및 $1,000 \mu \mathrm{g} / \mathrm{mL}$ 로 처리하였 으며, 모든 농도 구간에서 세포 생존율을 $90 \%$ 이상으로 유지시켜 RAW264.7 세포에 대한 독성이 낮음을 확인하였 다.

대식세포는 인체에 항원인 박테리아가 침입하였을 때 일차적인 면역반응을 담당하는 세포로서, 이러한 박테리아 를 사멸시키기 위해 대식세포는 다양한 물질을 분비한다. 그중에서 nitric oxide(NO, 일산화질소)가 대표적인 물질로 알려져 있다(38). 추출용매에 따른 무처리 및 증숙 산수유 추출물의 면역활성을 확인하기 위해 lipopolysaccharide (LPS, $0.1 \mathrm{\mu g} / \mathrm{mL}$ )로 자극을 유도한 RAW264.7 세포를 이용 하여 nitric oxide 생성에 미치는 영향을 분석한 결과, 대조 군(control) 및 LPS 처리군이 각각 $5.86 \mu \mathrm{M}$ 및 $33.05 \mu \mathrm{M}$ 로 나타났으며, 대조군(control)에 비해 무처리 및 증숙 산수유 추출물이 모든 농도에서 nitric oxide 생성량이 증가하였다. 모든 추출용매에서 증숙 산수유 추출물이 무처리 산수유 추출물에 비해 nitric oxide 함량이 증가하였으며, 그 중 증숙 산수유의 $50 \%$ 에탄올 추출물 $(100-1,000 \quad \mu \mathrm{g} / \mathrm{mL})$ 에서 $10.02-15.70 \mu \mathrm{M}$ 로 가장 높은 nitric oxide 함량을 나타내었 다. Lee 등(39)은 산수유 에탄올 추출물이 흥선 및 비장 림프구의 증식을 촉진시키며, 복강 대식세포의 탐식능 및 nitric oxide 생성을 유발하여 면역을 조절하는 작용이 있다 고 보고하였다. 또한 nitric oxide의 비특이적 숙주방어기작 대식작용, 세균 및 암세포의 생육억제활성이 증명된 바가 
있으며(40), 활성화된 대식세포에서 생산되는 암세포의 중 요 숙주 방어물질로 인정된 TNF- $a$, IL-1 $\beta$ 와 같은 cytokines 은 nitric oxide의 중간물질 발생과 연관성이 높은 것으로 알려져 있어(41) nitric oxide 함량이 가장 높게 나타난 증숙 산수유의 $50 \%$ 에탄올 추출물이 우수한 항암 활성을 나타낼 것으로 사료된다.

\section{(A)}

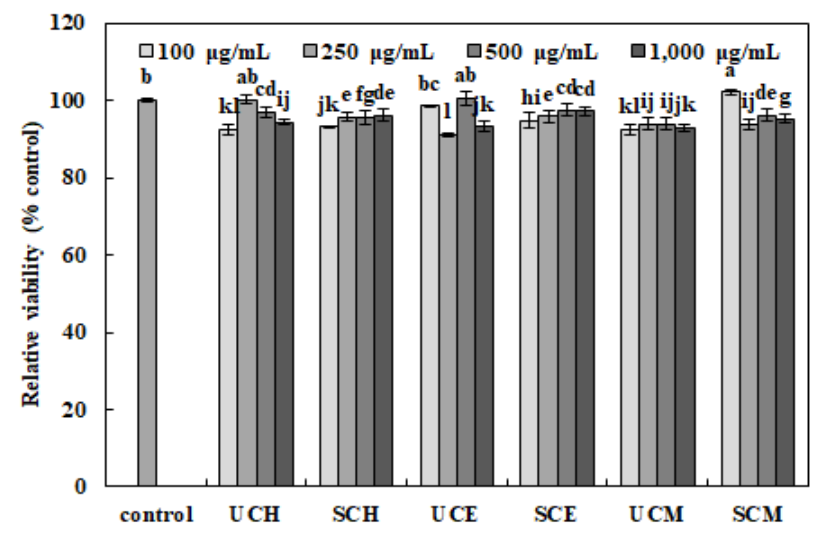

(B)

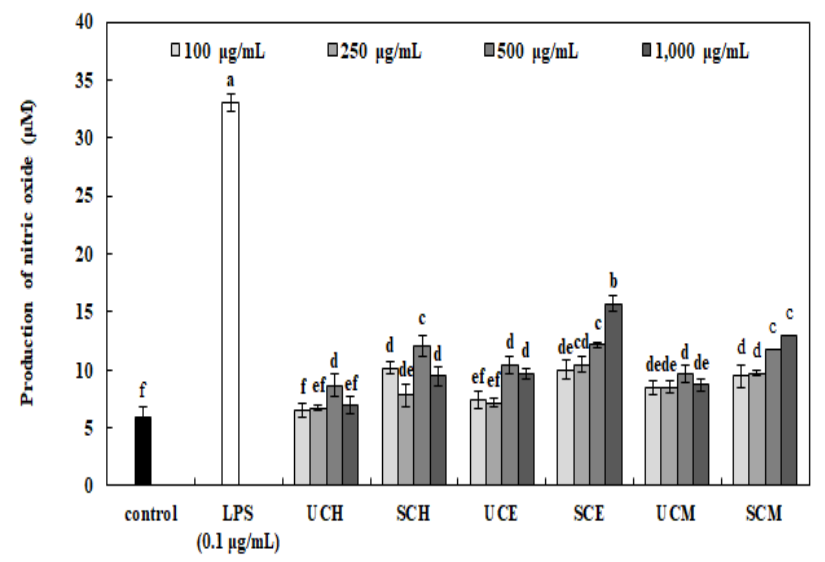

Fig. 3. Cell viability (A) and nitric oxide production (B) in RAW264.7 cell line of extracts from untreated and steam-treated corni fructus.

UCH, hot-water extract of untreated Corni fructus, SCH, hot-water extract of steam-treated Corni fructus, UCE, 50\% ethanol extract of untreated Corni fructus, SCE, 50\% ethanol extract of steam-treated Corni fructus, UCM, 50\% methanol extract of untreated Corni fructus, SCM, 50\% methanol extract of steam-treated Corni fructus.

Means \pm SD ( $n=3)$ with different letters $(a-1)$ above bars are significantly different by Duncan's multiple range test $(\mathrm{p}<0.05)$.

\section{암세포 생육 저해활성}

추출용매에 따른 무처리 및 증숙 산수유 추출물의 인간 자궁경부암 세포주인 $\mathrm{HeLa}$ 및 인간 유방암 세포주인 MCF-7에 대한 생육 저해활성 결과는 Fig. 4와 같다. HeLa 및 MCF-7 세포에 추출용매에 따른 무처리 및 증숙 산수유 추출물 $(100,250,500$, 및 $1,000 \mu \mathrm{g} / \mathrm{mL})$ 과 양성 대조군으로 doxorubicin $(1 \mu \mathrm{gg} / \mathrm{mL})$ 을 처리하여 48시간 배양한 후 암세포 생육 저해활성을 측정하였다. 모든 시료에서 농도가 증가 함에 따라 암세포 생육 저해활성이 증가하였으며, HeLa 및 MCF-7 세포 생육 저해활성은 증숙 산수유의 $50 \%$ 에탄 올 추출물 $(1,000 \mu \mathrm{g} / \mathrm{mL})$ 에서 각각 $56.94 \%$ 및 $41.94 \%$ 로 암 세포 생육 저해활성을 나타내었다. 이는 대식세포의 nitric oxide 함량과 유사한 경향을 나타내어 nitric oxide 생성량이 암세포 생육과 연관 있음을 확인하였다. Jeon 등(42)의 연구 에서 산수유 에탄올 추출물이 자궁암 $\mathrm{HeLa}$ 세포의 증식을 농도 의존적으로 억제하였다고 보고하였으며, $\operatorname{Kim}$ 등(16) 은 산수유 에탄올 추출물은 유방암 MCF-7 세포뿐만 아니 라 폐암 A549 세포의 증식을 유의하게 억제시켜 암세포의 세포주기 변화 등 항암에 우수한 효과가 있다고 보고하였다.

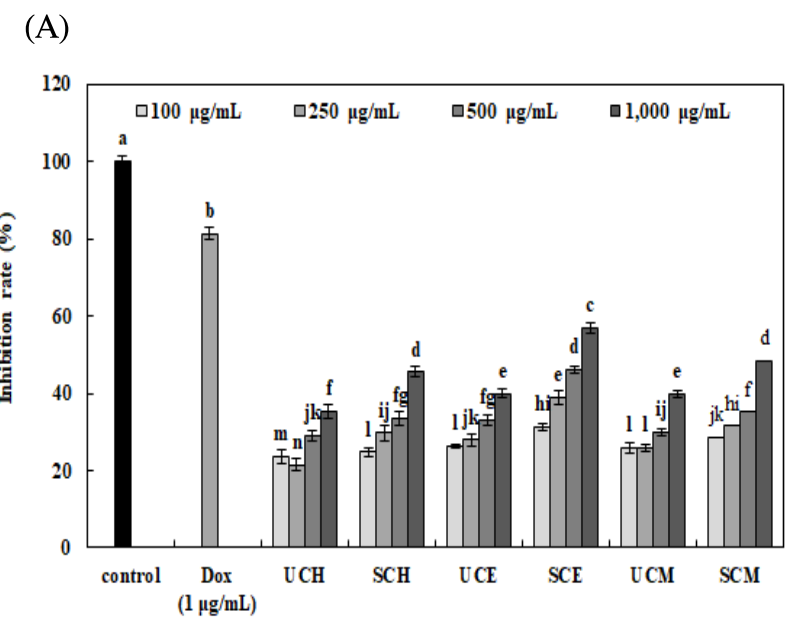

(B)

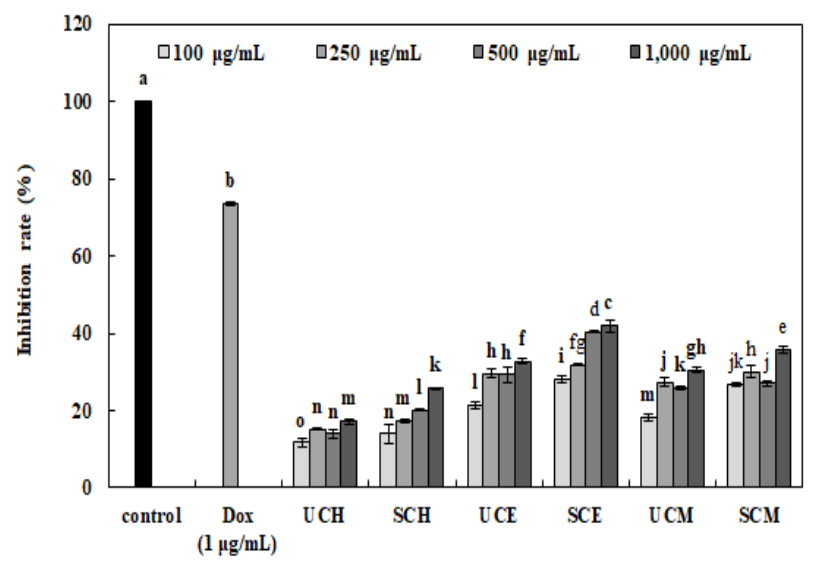

Fig. 4. Inhibition rate (MTT assay) in HeLa cell line (A) and MCF-7 cell line (B) of extracts from untreated and steam-treated corni fructus.

UCH, hot-water extract of untreated Corni fructus, SCH, hot-water extract of steam-treated Corni fructus, UCE, 50\% ethanol extract of untreated Corni fructus, SCE, 50\% ethanol extract of steam-treated Corni fructus, UCM, 50\% methanol extract of untreated Corni fructus, SCM, 50\% methanol extract of steam-treated Corni fructus.

Means $\pm S D(n=3)$ with different letters (a-0) above bars are significantly different by Duncan's multiple range test $(\mathrm{p}<0.05)$. 


\section{요 약}

본 연구에서는 증숙 공정을 전처리로 적용하여 추출용매 에 따른 산수유 추출물의 항산화 및 생리활성을 비교 분석 하였다. 추출용매에 따른 무처리 및 증숙 산수유 추출물의 추출수율은 13.20-47.45\%로, 증숙 산수유보다 무처리 산수 유의 추출수율이 높게 나타났다. 총 폴리페놀 및 총 플라보 노이드 함량은 증숙 산수유 $50 \%$ 에탄올 추출물에서 각각 $12.23 \mathrm{~g} / 100 \mathrm{~g}$ 및 $5.08 \mathrm{~g} / 100 \mathrm{~g}$ 으로 높은 함량을 나타내었으 며, 총 당 함량은 증숙 산수유 열수추출물에서 $71.32 \mathrm{~g} / 100$ $\mathrm{g}$ 으로 높은 함량을 나타내었다. 유기산 함량은 증숙 공정을 통해 citric acid, malic acid, 및 formic acid 함량은 감소하였 고 oxalic acid 및 gallic acid 함량은 증가하였으나, 유기산은 대체로 감소되었다. DPPH radical 소거활성, ABTS radical 소거활성 및 $\mathrm{FRAP}$ 활성은 증숙 산수유 $50 \%$ 에탄올 추출물 $(1,000 \mu \mathrm{g} / \mathrm{mL})$ 이 각각 $72.37 \%, 43.15 \%$ 및 $689.49 \mu \mathrm{M}$ 로 가장 우수한 항산화 활성을 나타내었다. $50 \%$ 에탄올 추출물 $(1,000 \mathrm{\mu g} / \mathrm{mL})$ 은 $\mathrm{H}_{2} \mathrm{O}_{2}$ 에 의해 손상된 폐상피세포인 L-132 세포에서 $87.37 \%$ 로 가장 높은 세포생존율을 나타내었으며, LPS로 자극을 유도한 대식세포주인 RAW264.7 세포에서 $15.70 \mu \mathrm{M}$ 로 가장 높은 nitric oxide 생성량을 나타내었다. 또한 자궁경부암(HeLa) 세포 및 유방암(MCF-7) 세포에서 각각 $56.74 \%$ 및 $41.94 \%$ 의 암세포 생육 저해활성을 나타내 었다.

\section{References}

1. Byun MW (2013) Immunomodulatory activities of apple seed extracts on macrophage. J Korean Soc Food Sci Nutr, 42, 1513-1517

2. Blois MS (1958) Antioxidant determinations by the use of a stable free radical. Nature, 181, 1199-1200

3. Valko M, Leibfritz D, Moncol J, Cronin MTD, Mazur M, Telser J (2007) Free radicals and antioxidants in normal physiological functions and human disease. Int J Biochem Cell Biol, 39, 44-84

4. Branen AL (1975) Toxicology and biochemistry of butylated hydroxyanisole and butylated hydroxytoluene. J Am Oil Chem Soc, 52, 59-63

5. Cheo SY, Yang KH (1982) Toxicological studies of antioxidants, butylated hydroxytoluene (BHT) and butylated hydroxyanisole (BHA). Korean J Food Sci Technol, 14, 283-288

6. da Silva JMR, Rigaud J, Cheynier V, Cheminat A, Moutounet M (1991) Procyanidin dimers and trimers from grape seeds. Phytochemistry, 30, 1259-1264
7. Kim HJ, Han CH, Kim NY, Lee EK, Lee KN, Cho HE, Choi YH, Chong MS (2010) Effect of garlic extracts with extraction conditions on antioxidant and anticancer activity. Korean J Orient Physiol Pathol, 24, 111-117

8. Chung SR, Jeune KH, Park SY, Jang SJ (1993) Toxicity and lectins constituents from the seed of Corni fructus. Korean J Pharmacogn, 24, 177-182

9. Lee JY (2003) Iridoid glycosides of Cornus officinalis. MS Thesis, Seoul national University, Korea, p 30

10. Seo KI, Lee SW, Yang KH (1999) Antimicrobial and antioxidative activities of Corni fructus extracts. Korean J Postharvest Sci Technol, 6, 99-103

11. Lee SO, Han SM, Kim HM, Jeung SK, Choi JY, Kang IJ (2006) Chemical components and antimicrobial effects of Corni fructus. J Korean Soc Food Sci Nutr, 35, 891-896

12. Tian G, Zhang T, Yang F, Ito Y (2000) Separation of gallic acid from Cornus officinalis sieb. et Zucc by high-speed counter-current chromatograghy. J Chromatogr A, 886, 309-312

13. Kim YE, Lee YC, Kim HK, Kim CJ (1997) Antioxidative effect of ethanol fraction for several Korean medicinal plant hot water extracts. Korean J Food Nutr, 2, 141-144

14. Kim OK (2005) Antidiabetic and antioxidative effects of Corni fructus in streptozotocin-induced diabetic rats. Korean J Oil Chem Soc, 2, 157-167

15. Kim BH, Park KU, Kim JY, Jeong IY, Yang GH, Cho YS, Lee ST, Seo KI (2004) Purification and characterization of anticarcinogenic compound from Corni fructus. Korean J Food Sci Thechnol, 36, 1001-1007

16. Lee YC, Kim YE, Lee BY, Kim CJ (1992) Chemical compositions of Corni fructs and separating properties of its flesh by drying. Korean J Food Sci Technol, 24, 447-450

17. Kang MK, Kim JS, Kim GC, Choi SY, Kim KM (2015) Evaluation of physicochemical properties and enhancement of antioxidant activities of Dioscorea batatas by stepwise steaming process. J East Asian Soc Diet Life, 25, 1049-1057

18. Song CH, Seo YC, Choi WY, Lee CG, Kim DU, Chung JY, Chung HC, Park DS, Choong JM, Lee HY (2012) Enhancement of antioxidative activity of Codonopsis ianceolata by stepwise steaming process. Korean J Med Crop Sci, 20, 238-244

19. Park JH (2011) Preparation of red doraji extract and quality properties by extract and aging condition. MS Thesis, Joongbu University, Korea, p 38 
20. Im GY, Jang SY, Jeong YJ (2010) Quality characteristics of Panax ginseng C. A. Meyer steaming heat and wet grinding conditions. J Korean Soc Food Sci Nutr, 39, 1005-1010

21. Kang MK, Kim JS, Kim GC, Choi SY, Kim KM (2016) Quality characteristics of pancake premix with Dioscorea batatas powder by steaming process. Korean J Food Cookery Sci, 32, 593-599

22. Singleton VL, Rossi JA (1965) Colorimetry of total phenolics with phosphomolybdic-phosphotungstic acid reagents. Am J Enol Vitic, 16, 144-158

23. Zhishen J, Mengcheng T, Jianming W (1999) The determination of flavonoid contents in mulberry and their scavening effect on superoxide radicals. Food Chem, 64, 555-559

24. Dubois M, Gilles KA, Hamilton JK, Rebers PA, Smith F (1956) Colorimetric method for determination of sugars and related substance. J Anal Chem, 28, 350-356

25. Re R, Pellegrini N, Proteggente A, Pannala A, Yang M, Rice-Evans C (1999) Antioxidant activity applying an improved ABTS radical cation decolorization assay. Free Radical Biol Med, 26, 1231-1237

26. Benzie IF, Strain JJ (1986) The ferric reducing ability of plasma (FRAP) as a measure of "antioxidant power" the FRAP assay. Anal Biochem, 239, 70-76

27. Hwang EG (2003) Protective effects of a-tocopherol and captopril against hydrogen peroxide-induced apoptosis on human lung epithelial cell line L-132. Ph D Thesis, Kyunghee University, Korea, p 32

28. Kim HJ, Cha JY, Choi ML, Cho YS (2000) Antioxidative activities by water-soluble extracts of Morus alba and Cudrania tricuspidata. J Korean Soc Agric Chem Biothchnol, 43, 148-152

29. Kim EY, Baik IH, Kim JH, Kim SR, Rhyu MR (2004) Screening of the antioxidant activity of some medicinal plants. Korean J Food Sci Technol, 36, 333-338

30. Choi Y, Lee SM, Chun J, Lee HB, Lee J (2006) Influence of heat treatment on the antioxidant activities and polyphenolic compounds of shiitake (Lentinus edodes) mushroom. Food Chem, 99, 381-387

31. Hong HD, Kim YC, Rho J, Kim KT, Lee YC (2007) Physicochemical properties of Panax ginseng C.A. meyer during repeated steaning process. J Ginseng Res, 31, 222-229
32. Aida TM, Tajima K, Watanabe M, Saito Y, Kuroda K, Nonaka T, Hattori H, Smith Jr RL, Arai K (2007) Reactions of D-fructose in water at temperatures up to $400^{\circ} \mathrm{C}$ and pressures up to $100 \mathrm{MPa}$. J Supercrit Fluid, 42, 110-119

33. Middleton E, Kandaswami C (1994) Potential healthpromoting properties of citrus flavonoids. Food Technol, 48, 115-119

34. Choo BK, Chung KH, Seo YB, Roh SS (2013) Antioxidant, antiinflammation and hepatoprotective activity of Schizandrae fructus processed with differenciated steaming number. Korean J Herbol, 28, 83-92

35. Yang SJ, Woo KS, Yoo JS, Kang TS, Noh YH, Lee JS, Jeong HS (2006) Change of Korean ginseng components with high temperature and pressure treatment. Korean J Food Sci Technol, 38, 521-525

36. Shin JH, Lee SJ, Seo JK, Cheon EW, Sung NJ (2008) Antioxidant activity of hot water extract from yuza (Citrus junos SIEB ex TANAKA) peel. Korean J Life Sci, 18, 1745-1751

37. Kwak JH, Jo YN, Jeong JH, Kim HJ, Jin SI, Choi SG, Heo HJ (2013) Protective effects of black soybean seed coat extracts against oxidative stress-induced neurotoxicity. Korean J Food Sci Technol, 45, 257-261

38. Kang HI, Kim JY, Moon KD, Seo KI, Cho YS, Lee SD, Yee ST (2004) Effect of the crude polysaccharide of Pleurotus eryngii on the activation of immune cells. J Korean Soc Food Sci Nutr, 33, 1092-1097

39. Lee WB, Jung HS, Kwon J, Oh CH, Lee KG (2002) Immunoregulatory action of Corni fructus Sicb. et Zucc. Korean J Orient Physiol Pathol, 16, 267-271

40. Duerksen-Hughes PJ, Day D, Laster SM, Zachariades NA, Aquino L, Gooding LR (1992) Both tumor nectosis factor and nitric oxide participate in lysis of simian virus 40 transformed cells by activated macrophages. J Immunol, 149, 2114-2122

41. Vane JR, Mitchell JA, Appletom I, Tomlinson A, Bailey DB, Croxtall J, Willoughby DA (1994) Inducible isoforms of cyclooxygenase and nitric oxide synthetase in inflammation. Proc Natl Acad Sci USA, 91, 2046-2050

42. Jeon YH, Kim MH, Kim MR (2008) Antioxidative antimutagenic and cytotoxic activities of ethanol extracts from Cornus officinalis. J Korean Scr Food Sci Nutr, $37,1-7$ 